\title{
SOME ISSUES IN THE GOVERNMENT SUBSIDY OF HOSPITALS IN NEW SOUTH WALES: 1858-1910
}

\author{
by \\ MICHAEL HORSBURGH*
}

FROM THE beginning of the voluntary hospital system of New South Wales in 1827, government support by way of subsidy was a significant feature both of hospital income and of government expenditure. ${ }^{1}$ From 1863 government expenditure on hospitals was greater than its expenditure on all other subsidized charities. The large amounts dispersed by way of matched and special grants and per capita payments were distributed to an ever-growing number of organizations, which effectively mirrored the progress and development of New South Wales. Thirteen hospitals were in receipt of subsidy in 1858 and 130 in 1910. They represented the most extensive form of charitable endeavour throughout the colony, and were the purveyors of both indoor and outdoor relief to the sick poor. Their facilities were often primitive and their nursing staff untrained. Despite objections from medical specialists and reactions from local authorities they provided assistance in the form of benevolent asylums in areas where the capacity to support different institutions was low and the demand for service was not overwhelming. In the metropolitan centre of Sydney the hospitals were among the great charitable institutions, founded and governed by voluntary workers and subscribers, and, in their own eyes at least, assisted, in recognition of their good works, by government money.

Sickness and poverty go hand in hand, no less in the nineteenth century than in the twentieth. If it is considered that employment is available for able-bodied adult males and that consequently poverty among them is largely of their own making, the poor for whom provision must be made are dependent women and children, the aged and the sick. The former two groups were cared for in special institutions and the two latter formed the loosely defined clientele of the hospitals and benevolent asylums. Their distribution between the two kinds of facilities available was dependent on a number of factors, including: the services actually available in any area, the state of medical knowledge and treatment, and the costs of caring for different groups. Developments in the areas implied by these factors led gradually to greater clarity in the way in which the tasks of the institutions were defined.

Medical care is, however, different from the provision of asylums for the indigent.

*Michael Horsburgh, B.A., M.S.W., Lecturer in Social Administration, Department of Social Work, University of Sydney, Australia.

${ }^{1}$ This paper has been adapted from M. D. Horsburgh, 'Government subsidy of voluntary social welfare organisations: a case study: N.S.W, 1858-1910' unpublished Master of Social Work Thesis, University of New South Wales, 1975.

The author wishes to acknowledge the permission kindly granted by the Archives Authority of New South Wales to publish material from its holdings. 


\section{Issues in the government subsidy of hospitals in New South Wales}

In theory disaster and misfortune may strike us all, and the "decayed gentry" may be no less poor than those who have never been in any position to suffer a decline in their fortunes. Nevertheless, the probability that all may become sick is much higher than the probability that all may become poor. It may appear even higher if sickness is generally regarded as a misfortune while poverty is a punishment. The growth of knowledge in the physical sciences relieved sufferers of the personal responsibility for most of their illnesses long before the social sciences altered the moral approbation placed on the unemployed. It is also apparent that the successful treatment of all sick persons involves the application of appropriately similar remedies. It involves the same kinds of trained personnel, medical practitioners and nurses. The question is how the available services are to be distributed among the persons who might need them. Given that the alternative to treatment was often death, there were some limits to be placed on the operation of purely laissez-faire market considerations.

The nineteenth century saw great advances in the diagnosis and treatment of medical conditions, which served to highlight the common nature of the risks shared by the community. The introduction of effective public health measures further moved medical care into the area of general public service. Towards the end of the century hospitals were looked upon as places to go for treatment, treatment which might benefit all classes, rather than as refuges for the incurable and dying poor.

Thus three factors may be seen to lie behind the special position of hospitals in the charitable organization of New South Wales. (1) The widespread distribution of the organizations, which made them indigenous social structures, difficult to control or alter. In varying degrees they were part of the social fabric of both village and metropolis. (2) The common liability to disease to be treated by the same methods. This gave a wide group of citizens a stake in the availability of provision and raised the question of its equitable distribution. (3) The presence of trained personnel whose services were common to both rich and poor, and whose social status was increased by the growth of scientific expertise.

These factors placed great demands on government to provide increasing support for hospital services, but also functioned to deprive it of the possibility of undertaking direct state provision of medical and hospital care. Thus country hospitals continued to be built on the basis of local demands rather than assessed needs, and the rivalry between the two metropolitan hospitals led to stop-start building policies in Macquarie Street which lasted until 1894. The government administrative machinery was not equal to the controlling of a widespread range of services, even if practical politics had made such a move feasible. Thus the problem of rising costs could not be solved by controlling hospitals directly. The amount of investment in the existing system prevented a series of competitive hospitals from being established.

\section{COUNTRY HOSPITALS}

The widespread network of country hospitals provided the most difficult administrative problems for the subsidizing authorities. The proportion of country hospital income received from government sources was not usually less than fifty per cent, as could be anticipated when a matching $£ 1: £ 1$ subsidy scheme was widely available. 


\section{Michael Horsburgh}

It is not clear from the figures published in the Statistical register of New South Wales, how much income was received by way of fines and unclaimed poundage, which were made available to hospitals by various statutes, nor is it possible to tell whether the sums so received were universally regarded by hospital authorities as being received from government sources. ${ }^{2}$ None of the institutions was in an independent financial position, with the early exception of the Windsor Hospital, conducted in the former military hospital buildings by the Hawkesbury Benevolent Society. In 1856 only fifteen per cent of its income was received by way of any form of subsidy. Voluntary contributions assisted in providing the balance, but the society stated that the "principal source is a herd of cattle possessed by the Institution". 3 This hospital maintained a high proportion of independent income throughout the period, although from 1892 onwards, when the Statistical register of New South Wales provided information on more discrete categories of income, the main source had been altered to interest on investments. Its early experiment in what must be the equivalent of a commercial venture, marked a singular departure from the usual attempts to maintain independence from government assistance. This source of income was not generally exploited.

Some institutions had in 1856 provisions for payments by or on behalf of patients. The charges ranged from $1 s .6 \mathrm{~d}$. per day at Brisbane to $2 \mathrm{~s} .6 \mathrm{~d}$. per day at Goulburn, but as the authorities of the former noted, the receipts from patients rarely exceeded $£ 3$ (equivalent to thirteen days) as the patients were by then "virtually paupers".4 This seems to indicate that the question of extending the service of hospitals through the admission of paying patients is more appropriately at this early date to be regarded as part of the pauperizing tendency of the hospital system. If a patient was not originally entirely without resources, he very quickly became so. Any further treatment was on the basis of charity. The subject of payment gained greater prominence when paying patients desired to make use of the improved facilities available.

The returns from hospitals in response to government requests varied greatly in the completeness and clarity of the data they provided and would not have formed the basis for the development of a comprehensive government policy. Apart from direct requests for information, the government was obliged to use its only widespread arrangement, the police and court system. Police officers and magistrates were, when particular information was required, the appropriate government agents. This ad hoc use of persons generally unfamiliar with the needs and problems of the hospitals was hardly a remedy for the inadequacies of the institutions themselves. The gap only began to be filled when the Inspector of Public Charities began both to require accurate returns and to visit the institutions themselves. But as late as 1893 the inability of hospitals to comply with requests for information was still a problem. ${ }^{5}$

\footnotetext{
2 Documents in Colonial Secretary Special Bundle (C.S.S.B.) (State Archives of New South Wales), 4/721.1 reveal an inconsistent practice. Tamworth Hospital listed income as being received from voluntary contributions, fines and poundage, and government aid, whereas Goulburn Hospital included fines and poundage and government aid in the same category.

Return contained in ibid.

4 Ibid.

- Report on the subsidized hospitals of New South Wales, Votes and Proceedings, Legislative Assembly of New South Wales (V. \& P.L.A.) 1894/95, vol. 5. p. 519.
} 


\section{Issues in the government subsidy of hospitals in New South Wales}

In 1908 the Secretary of Manly Cottage Hospital protested against the increasing demands being made on hospitals for the supply of information.

With every respect I would urge upon the Chief Secretary to refrain from multiplying Books of Account in connection with our Hospitals. The position of Treasurer is always an Honorary position, and any complicated set of Account Books would probably have to be written up by the Secretary, who in our case, as also in many other Hospitals, is an Honorary Officer, and Secretaryies [sic] are already heavily burthened with statistical information and other returns for the Board of Health."

The Dubbo Hospital was of the opinion that a better set of arrangements would be arrived at if the chief secretary sponsored a meeting of the secretaries of twelve major country hospitals for that purpose. ${ }^{7}$ The hospitals apparently felt remote from contact with the central authorities, the reverse of the situation so eloquently and frequently the subject of government memoranda. The spirit at least of the comments could have as easily reflected the position as it had been fifty years earlier.

By 1873, when the Royal Commission on Public Charities began its work, the administrative state of the hospitals had not markedly altered from that which had prevailed decades earlier. ${ }^{8}$ Various incidents occurring in individual country hospitals made significant contributions to the development of a system of control over subsidy arrangements. An application from Maitland Hospital in 1847 brought to notice the inadequate legal status of hospitals, and led to the passing of the Hospitals Act of $1848 .^{\circ}$

The Annual Estimates for $1870^{10}$ included for the first time the standard formula which was to become known, even in formal parliamentary documents as "the usual conditions". This formula provided that matched grants were subject to the condition that persons recommended by government officials were to be admitted or attended to without charge. This condition did not apply to special grants made for specific purposes. Dispute over the use of public money which occurred in Yass and Queanbeyan in $1861^{11}$ had shown, that even direct legislative provision took second place to the desire of local committees to upgrade the status of their institutions. The refusal of local authorities to abide by this condition and admit recommended cases to their hospitals caused problems for police and magistrates. ${ }^{12}$ The only available alternative was to commit the poor to Sydney gaol for a short period. They would be transferred to Sydney at government expense and then be placed in one of the government asylums.

Failure to admit destitute persons was not only the result of the search for increased status. In common with all institutions of the period, country hospitals were unable

- Colonial Secretary's In-Letter (C.S.I.L.) (State Archives of New South Wales) 08/15187, with C.S.S.B. op. cit., note 2 above, 5230. See also similar comments from other hospitals in C.S.S.B. 7552.

? C.S.I.L., op. cit., note 6 above, $08 / 14933$ with C.S.S.B., op. cit., note 2 above, 5230.

8 See hospital returns in the records of the Public Charities Commission, ibid., 4/1083.

'C.S.I.L., op. cit., note 6 above, 47/10373, with C.S.S.B., op. cit., note 2 above, 4776.4. The Act was II Vic. No. 59.

${ }^{10}$ V. \& P.L.A., op. cit., note 5 above, 1870 , vol. 1, p. 869.

11 Correspondence re relief of Poor Persons by Benevolent and Hospital Societies and the use of fines applicable thereto. Ibid., 1861/62, vol. I, p. 981 .

12 Documents concerning some of these case are collected in C.S.S.B., op. cit., note 2 above, 4/809.1. 


\section{Michael Horsburgh}

to treat infectious diseases. Their slender resources and generally primitive conditions did not allow for the erection of separate infectious wards where sufferers might at least be housed. In 1886 the case of Ellen Keihone of Gundagai brought matters to a head. Keihone, a woman of about sixty years of age, of eccentric disposition and intemperate habits, lived on the outskirts of the town. She contracted erysipelas, a highly infectious skin condition, but was refused admission to the local hospital, a subsidized institution. The police and the government medical officer were obliged to make other and much less satisfactory arrangements for her. Due to a combination of her disposition and habits she set fire to her clothing and suffered severe burns to the upper part of her body. Her infectious skin condition still excluded her from admission to the Gundagai Hospital and she subsequently died. The combination of both accidental injuries and an infectious disease posed a severe dilemma for the hospital authorities and the subsequent inquiries produced conflicting conclusions regarding the culpability of the various persons involved..$^{13}$

The administrative reaction was to place the onus clearly on the shoulders of the hospital authorities. On the recommendation of the medical adviser to the government (MacLaurin) ${ }^{14}$ the Colonial Secretary issued the following circular:

The Medical Adviser to the Government having drawn attention to cases where admission has been refused to pauper patients by the authorities of certain Hospitals, I am directed by the Colonial Secretary to inform you that it had been decided, that in cases where the authorities of a Hospital refuse to undertake the treatment of a sick pauper, all expenses connected with the treatment of such a person by the Government will be deducted from the subsidy paid to the Hospital. ${ }^{16}$

An appropriate deduction was made from the subsidy due to Gundagai Hospital.

It can hardly be said, however, that this reaction contributed to a resolution of the particular difficulty involved in the Keihone case. As late as 1903, F. Norton Manning was making the same complaints about country institutions, and endeavouring by the issue of ever more strongly worded circulars to enforce the same remedy. ${ }^{16}$ The problem was basically one of requiring small institutions to cope with diverse and conflicting needs. The concern of the government that it paid twice for the same service was understandable, but only increased provision could alleviate the difficulty. As conditions which bound committees of institutions, the "usual conditions" worked only as and when they were practicable.

That, in the Keihone case, the death of a patient led to the identification of a general problem, rather than the simple conclusion that individual responsibility had broken down, is an indication both of ultimate government responsibility in matters of life and death, and of the amount of pressure required to bring the conditions existing in country hospitals to the operative attention of the central administration. The problem of the unwillingness of hospital boards to receive some classes of patients, and the inadequacy of the institutions themselves were well known, but generally

18 The papers referring to this case are with C.S.I.L., op. cit., note 6 above, $86 / 9158$.

14 Ibid., 86/5028 with 86/9158.

15 Both the draft and a printed copy of the circular are with ibid., 86/9158.

16 Department of Public Health Book of precedents and instructions, State Archives of New South Wales (Box 5852) p. 57. 


\section{Issues in the government subsidy of hospitals in New South Wales}

failed to produce action of a deliberate kind. The action which resulted from the Keihone case failed completely to assist hospitals to make the kinds of provisions required, while it penalized them for their inevitable failures.

Two other contemporary events illustrate the inequities of the subsidy process. In July 1885, the residents of Silverton, a mining town near Broken Hill, on the Western border of the State, sent a deputation to the Minister for Mines to request a special grant of $£ 1,000$ for the hospital of that town. Their arguments were sufficiently persuasive to cause the minister to agree to the request, although the matter was not in his jurisdiction. ${ }^{17}$ The deputation was followed up by a letter in May 1886, addressed to the Colonial Secretary's Department, and enquiring when the promise was to be honoured. ${ }^{18}$ In commenting upon the request, the Inspector of Public Charities noted the inequitable results of this political interference involved in the case. The Silverton Hospital had treated only thirty-seven patients in 1884, and he considered that the normal matching subsidy of $£ 200$ was sufficient for a hospital of that size. ${ }^{19}$ The grant was paid.

The refusal of the authorities at the Carcoar Hospital to admit a patient suffering from erysipelas to their hospital, as those at Gundagai had done with Ellen Keihone, led to an investigation and report by the inspector of public charities. He sympathetically reported the problems facing the hospital board, since not only was the hospital quite full at the time, but there was no isolation ward into which the patient could have been admitted. The risks of admission would have been borne by the other patients who were already in overcrowded and inadequate accommodation. ${ }^{20}$ The police magistrate for the district pursued the matter by requesting, through the Department of Justice, a special grant of $£ 100$ for the erection of an erysipelas ward. ${ }^{21}$ The request was welcomed by the inspector who commented that there should be an infectious diseases ward in every country hospital. The Colonial Secretary (George Dibbs) minuted: "I regret I cannot accede to this." 22

These incidents revealed not only the general inadequacies of the country hospitals, but the inflexibility of the subsidy arrangements used. The general $£ 1: £ 1$ matched grant was adequate only for regular administration, and did not allow for additional expenditure. Those needs were met by special grants, some of which were also matched to voluntary contributions, particularly where the hospitals had opened a special building fund, but which were more often granted directly. They were subject to political influence and did not direct resources to the solution of known problems in a consistent manner. Despite the knowledge available, there was no suggestion that special kinds of buildings or developments should receive priority. Instead, the major suggestion was to prevent the granting of excessive sums, by the application of further matching arrangements.

Inspector of public charities Robison drew attention to the disadvantageous effects of the funding arrangements in a submission to the Colonial Secretary Dibbs:

\footnotetext{
${ }^{17}$ C.S.I.L., op. cit., note 6 above, 85/7834 with 86/5599.

18 Ibid., 86/5599.

10 Minute to ibid., 85/7834.

${ }^{20}$ Ibid., 86/7807 with 86/9328.

21 Ibid., 86/9328.

22 Ibid.
} 


\section{Michael Horsburgh}

... heretofore much irregularity has existed in making grants to country hospitals for building or extension purposes and they have been measured rather by the pressure brought to bear on the Government than by their merits.

The consequences of this want of a proper system are hard on the Treasury-demoralising to the public and often unfair to those districts most deserving of assistance. ${ }^{20}$

He proposed to regulate grants for building purposes by offering additional matched grants of $£ 2: £ 1$ on the ordinary subscriptions. Thus a hospital requiring additional funds and having annual subscriptions to the value of $£ 200$ would receive its regular subsidy of $£ 200$ plus, if its application were approved, $£ 400$ special building grant. "The terms proposed are sufficiently liberal while the principle of self-help is insisted upon. By the adoption of the above suggestion I venture to think demands on the Treasury will be lessened-yet all reasonable requirements amply met." ${ }^{24}$ Robison's proposal countered only half of the problem he perceived, i.e. the granting of excessive sums. It would not have prevented the use of political pressure to gain approval of applications, however the amount was computed. Dibbs was unimpressed and commented: "I do not see any way to lay down a hard and fast rule as proposed in this letter." 25

\section{PAYING PATIENTS}

There was some interest in improving the availability of country hospitals to the whole community. In 1878, noting that many artisans and other respectable working people declined to become patients because of the charitable associations of the institutions, Robison recommended that patients or their friends should be encouraged to pay a fee of $1 s$. per day which would be subject to a matched grant. ${ }^{26}$ That artisans held such an attitude was detrimental to their own position, since the conditions of the colony were such that many respectable itinerant workers had no fixed abode in which they might receive private assistance. ${ }^{27}$

The advantage of this plan would be the inculcation of feelings of self-reliance and self-respect, by paying at all events in part of the benefits received, instead of, as at present, inducing a widespread pauperising influence, the result of entirely eleemosynary aid; or it may be, raising a feeling of jealousy and discontent in the mind of the patient who is solicited for payment, on the ground that those around him in the wards have escaped that which under the circumstances he regards as an extortion. ${ }^{28}$

The connotation "charitable" should apply to country hospitals only in its highest interpretation, i.e. where the best in accommodation and skilled treatment was available ". . . to all who suffer, without reference to the pecuniary condition of the applicant, yet at the same time exacting strictly a fair and moderate return whenever the circumstances of the patient warrant the demand." ${ }^{29} \mathrm{He}$ referred again to this

28 Ibid., 86/3083.

24 Ibid.

${ }^{25}$ Ibid.

${ }^{26}$ Inspector of Public Charities Report, 1 March 1878, V. \& P.L.A., op. cit., note 5 above, 1877/78, vol. 2, p. 641 .

27 Ibid., 31 March 1879; 1878/79, vol. 3, p. 959.

28 Ibid., 1 March 1878, p. 641 .

20 Ibid., 31 March 1879, p. 959. 


\section{Issues in the government subsidy of hospitals in New South Wales}

proposal in his Sixth Report, stressing on that occasion a changed perception of the hospital and the possible financial advantages.

To raise our Hospitals from the position they now occupy in the public estimation-as being merely a kind of poor-house for the sick-I would suggest that the Government require all receipts from patients to be specified separately, and that it notify its willingness to subsidise them $£ 1$ to $£ 1$ in the same manner as it now does ordinary subscriptions. In this way a more healthy spirit will be infused into the public mind, the practice of paying for benefits received become general, and in the end calls upon the public revenue become lessened without jeopardising Hospital interests. ${ }^{20}$

Such a scheme could also be applied to the metropolitan hospitals, and was taken up in $\mathbf{1 8 8 5}$ by Colonial Secretary Stuart as one of a number of proposals he made for the reform of the hospital system. ${ }^{31}$ But no action resulted.

Robison's easy acceptance of the principle of payment in hospitals belied the opposition which the suggestion and the practice raised in other circles. Not only would the public perception of the role of the hospital be altered thereby, but the interests of medical practitioners would be affected. Most hospitals, both country and metropolitan, relied heavily on the services of honorary medical officers. The practice of paying medical officers in country hospitals had been thoroughly discouraged by inspector of public charities King in his reports, ${ }^{32}$ on the grounds of the costs involved, as well as the morality of the matter. It was not proper for doctors to earn money from charity. But, conversely, medical officers could only be expected to be honorary while the charitable nature of the institutions was preserved. The cost to the doctor of his honorary activity would of necessity be carried by his paying patients whose numbers should not be depleted by offers of cheap treatment in hospitals. The considerable professional benefits which might accrue to doctors through honorary services were not generally present in small country hospitals and were apparently not an overriding factor in Sydney. ${ }^{33}$

The issue of paying patients was the subject of considerable comment at the Royal Commission of 1898. Various medical witnesses asserted that the growth of private wards in public hospitals should be restricted. Dr. J. Ashburton Thompson, chief medical officer of the government and president of the board of health said:

... if a person can afford to pay his way entirely in a public hospital as a paying patient in a private ward, then the public hospital is exceeding its proper scope and its charitable design; such a person should rather be invited to enter a private hospital .... The public hospital should not interfere with the business carried on by those who own private hospitals. ${ }^{34}$

20 6th Report, ibid., 1882, vol. 2, p. 1021.

"1 Unregistered, printed document, 2 September 1885, with C.S.S.B., op. cit., note 2 above, 4/896.1.

"2 See C.S.I.L., op. cit., note 6 above, 72/2931, 72/234, 72/2933, 71/8626, 71/7728/2, 71/7729, 71/8609, 71/7298, 71/7927, with C.S.S.B., op. cit., note 2 above, 4/810.2.

${ }^{23}$ B. K. Dickey, 'Charity in New South Wales, 1850-1914', Ph.D. Thesis, Australian National University, 1966, p. 150.

${ }^{34}$ Royal Commission on Public Charities 1898, 4th Report, V. \& P.L.A., op. cit., note 5 above, 1899 (3rd Session), p. 610. For a strong counter-argument see L. Blair, Paying wards in public hospitals, Melbourne, 1877. T. J. Carter, 'On the system of cottage hospitals', Victorian Rev., January 1881, 5: $382-388$. 


\section{Michael Horsburgh}

But a dichotomy between totally free "charitable" provision and totally commercial "private" provision did not meet the case of those who fell into an "intermediate" position, as Dr. W. C. McLelland pointed out. ${ }^{35}$

The commission itself, although it did not recommend any alteration to existing subsidies, did acknowledge that there were essential differences between country and metropolitan hospitals. The narrow range of provision in country areas and the low demand made fee-paying acceptable. ${ }^{36}$ In the city, in addition to questions of unfair competition, the possible redirection of hospital activity away from the poor to other classes was to be resisted. It may even have occurred that hospitals would prefer paying patients to paupers. The possible effects of payment on the patients themselves were also noted.

... when patients pay even comparatively small sums towards their maintenance, they are relieved from all sense that they are, in a measure, recipients of charity; they have an idea that they are paying for their treatment, and accept hospital treatment when they otherwise would not; and because and on account of such payments, their demands on the attention of the nurses, and their requirements generally, are excessive. ${ }^{37}$

There was no support from the commission for a widening of the role of hospitals, nor for any subsidy based on promoting change. Nevertheless the practice of accepting paying patients grew and the proportion of total hospital income derived from patients' fees increased from eight per cent in 1892 to fifteen per cent in 1910.

\section{PAYING FOR POOR PATIENTS}

As a condition of subsidy, country hospitals were required to admit without charge patients referred by government officers. In making this condition, the government was operating on an analogy with the private contributors who were generally entitled to recommend patients for admission. The number of patients who could be recommended by individual subscribers was dependent on the size of the donation. In this sense, subscribers' recommendations could be seen as directing the expenditure of their own subscriptions. Since voluntary donations were matched by government grants, the government could be seen as having a power of admission at least equal to the sum of the private subscribers. This would lead to a virtually unlimited right in country areas where the demand was not high.

The system was defended by Ashburton Thompson in his evidence to the Royal Commission of 1898.

You know the present mode of subsidising the hospitals at $£$ per $£$, and the Government pays for

${ }^{35}$ Op. cit., note 34 above, p. 666 .

${ }^{36}$ Actual practices varied widely. Entries for Albury Hospital in the Statistical Register of New South Wales did not show any receipts from patients until 1898 and then only at a low level, whilst Armidale Hospital was receiving fees when a separate category was introduced into the Register and in some years they represented thirty to forty per cent of its income.

37 Op. cit., note 34 above, p. 511. See also ibid., Appendix F, p. 583: Proposals of the Hospital Reform Association: " 2 . To restrict treatment, both in the in-patient and the out-patient departments, to people who are not in a position to pay private practitioners." See also resistance to paying on the grounds of encouraging domestic virtues by requiring women to nurse patients at home, F. G. Holden, 'A pertinent question', Sydney quart. Mag., July 1885, pp. 174-178. 


\section{Issues in the government subsidy of hospitals in New South Wales}

patients in the metropolitan hospitals but does not pay for patients admitted under Government orders, in country hospitals; - have you any alteration to suggest? No; I have thought about that. The number of persons admitted to country hospitals on order of the Police or of Government Medical Officers is so small, and they stay such a very short time, that I think the care of them is a fair charge on the subsidy. ${ }^{38}$

As has already been noted, the problems raised by this condition reflected the inadequacy of the provision, and could not have been alleviated by any proposal to pay for patients when facilities were non-existent.

The situation in the metropolis was very different. Payment was made to the hospitals, originally Sydney Infirmary, and later Prince Alfred Hospital, on a per capita basis for pauper patients who were admitted on the Colonial Secretary's order. The original payment, commenced in 1838 , was at the rate of $1 \mathrm{~s} .9 \mathrm{~d}$. per day. ${ }^{39}$ In 1848 the government altered the basis of the payment from a fixed rate to an annually assessed rate which would pay for patients a sum which would "cover the expenses incurred on their account."40

On this basis rates were computed over a period of ten years as follows: ${ }^{41}$

$\begin{array}{ll}1848 & 1 s .0 d . \\ 1849 & 1 s .6 d . \\ 1850 & 1 s .3 d . \\ 1851 & 1 s .0 d . \\ 1852 & 1 s .3 d . \\ 1853 / 5 & 1 s .6 d . \\ 1856 / 7 & 1 s .10 d .\end{array}$

A major argument in the lowering of the rate was the government's assertion that at least some of the costs of the patients were borne by the matched subsidy available to the infirmary, ${ }^{42}$ and it was around this assertion that a dispute was to grow.

The rate of 1 s. $10 d$. per day was apparently maintained until 1868 , when the infirmary requested an increase to $2 s .8 d$. per day. Its claim was justified by dividing the costs of the hospital by the daily bed average number to arrive at a daily per capita cost, then regarded as actual outlay in the terms of the government's rule. ${ }^{43}$ In commenting upon this claim, inspector of public charities Walker noted that the records of the infirmary did not allow an adequate analysis of the way costs were distributed between indoor and outdoor patients. His best computation of the costs involved was $2 s .7 .344 d$. per day. But since he expected that the matched subsidy would cover the costs of staffing, he made a deduction of $8.17 \mathrm{~d}$. per day, to arrive at a figure of $1 s .11 \frac{1}{6} d .{ }^{44}$ On further investigation he discovered that in past computations

\footnotetext{
38 Op. cit., note 34 above, pp. 609-610.

30 K. Davies 'The problem of social distress in New South Wales in the two decades preceding the Gold Rushes, 1831-1851', M. A. Thesis, University of Sydney, 1961, p. 139.

${ }^{40}$ Minute attached to C.S.I.L., op. cit., note 6 above, with C.S.S.B., op. cit., note 2 above, $4 / 810.2$.

11 Ibid.

42 Memo dated 29 May 1847, with ibid.

ts C.S.I.L., op. cit., note 6 above, 86/5021, with C.S.S.B., op. cit., note 2 above, 4/810.2.

"4 Memo dated 25 September 1868 attached to ibid.
} 


\section{Michael Horsburgh}

the costs of building repairs had not been charged to the paupers' rate, although the cost of salaries had. Deducting both salaries and building repairs left him with a new rate of $1 s .7 \frac{1}{6} d$. per day, nearly $3 d$. less than the infirmary had been receiving. After negotiations, during which the government originally proposed a rate of $1 s .11 d$., the sum of $2 \mathrm{~s} .3 \mathrm{~d}$. was ultimately agreed upon, ${ }^{45}$ leaving only its commencement date as a matter for dispute. ${ }^{46}$

Walker's successor, King, continued his line of argument by comparing the costs at the infirmary, which amounted to 141 per annum, with those at the government asylums, of which King was secretary. The asylum cost was only $£ 12$ per annum or $8 d$. per day. The difference was too great, and King proposed that Walker's suggestion of $1 s$. $7 \frac{1}{2} d$. should be the basis of payment. ${ }^{47}$ In reply the infirmary authorities did not attempt to dispute the comparison, but simply referred to the agreement upon which the payments were based, the entire cost of maintenance. If Mr. King would examine the books he would see that the costs were accurately computed. ${ }^{48}$ This claim placed the matter on an apparent business footing. There was a contract, and regardless of all else the contract was being fulfilled by the infirmary. The infirmary had previously maintained this view of the arrangement in negotiations with the government over the granting of deeds to the property it occupied in Macquarie Street.

It seems scarcely necessary to add, that the large amount voted and expended for the treatment of pauper patients admitted into the Infirmary by order of the Government, cannot be regarded in the light of a subsidy or endowment chargeable against the institution. On the contrary, it is in reimbursement of a service rendered by it to the government and the public, and it is believed, quite as efficiently as it could be provided for in any public establishment, and at a much cheaper rate. ${ }^{10}$

The government did not share such a view of the relationship, but even if it had, King's argument disputed whether the cost was as low as it might be. But his case was weakened by the fact that he was unable to do more than assert that the difference between the two arrangements he had compared was too great. ${ }^{50}$ The differences of function made direct comparison invalid, and the assumption that the government asylums, where austerity was the rule, provided an adequate base measure was arbitrary, although not disputed by the infirmary. In this exchange the exact nature of the relationship involved had not been clarified and the agreement which depended upon it was similarly diffuse. The efforts of successive inspectors did not resolve the issue. There were other problems involved. The manner of claiming the subsidy was raised by Robison in 1885, when the rate for pauper patients was raised from 2s. $3 d$. to $3 s .{ }^{51}$ Sydney Hospital claimed payment for paupers at the end of each quarter. Accompanying the claim were the Colonial Secretary's orders authorizing

45 Memo dated 11 December 1868, with ibid.

46 C.S.I.L., op. cit., note 6 above, 68/7777, 70/2138, with C.S.S.B., op. cit., note 2 above, 4/810.2.

47 Ibid., $71 / 7773$.

18 Ibid., 72/946.

40 Correspondence re Sydney Infirmary Buildings, V. \& P.L.A., op. cit., note 5 above, 1868/69, vol. 3, p. 470.

so C.S.I.L., op. cit., note 6 above, 72/4753, with C.S.S.B., op. cit., note 2 above, 4/810.2.

s1 C.S.I.L., op. cit., note 6 above, 86/3083 with 86/4898. See also papers with C.S.S.B., op. cit., note 2 above, 4/896.1. The next rise was in 1903 when the rate became 3s. $6 d$. See C.S.I.L., op. cit., note 6 above, 0/713495, with C.S.S.B., op. cit., note 2 above, 5260. 


\section{Issues in the government subsidy of hospitals in New South Wales}

the admission of the patients. But where a patient remained in hospital beyond the end of a quarterly period, the order would be missing from subsequent claims. This necessitated considerable checking by the inspector's staff who had the task of verifying the claim.

Robison suggested that claims be submitted monthly, but not until the respective patients had been discharged. The order would accompany the claim as before, but only one claim would be made in respect of each patient. This was the method adopted at Prince Alfred Hospital. ${ }^{52}$ The infirmary agreed to the suggestion about monthly accounting, but ignored the other request, ${ }^{53}$ and Robison was obliged to try again. ${ }^{54}$ The hospital objected on the grounds that it would be delayed in the receipt of legitimate payments, and would in effect be doing too much on credit. ${ }^{55}$ It apparently chose to ignore the example of Prince Alfred Hospital, or perhaps reacted because of it. It also ignored the fact that the effect of which it complained was only short term, until the new system, with a regular turn-over of patients, was fully instituted. The matter was referred to the Treasury Inspectors who recommended that each month's account should include a list of those patients who had also appeared on the previous account. The list and the new vouchers would provide the necessary check. This solution was adopted. ${ }^{56}$

The monthly payment scheme was itself the product of further problems. There was little incentive for the hospitals to discharge patients promptly, since the orders given for admission were not subject to any re-assessment. It required some additional work to discover just how long patients were remaining in hospital. Robison suggested that orders be valid for only two months, after which time a new order would be required. ${ }^{57}$ The medical adviser to the government preferred a thirty-day period, and suggested that at the end of that time a government medical officer should be able to order the transfer of a patient to an appropriate government institution if necessary. ${ }^{58}$ This was approved.

The tendency of the hospital to exploit the system of government orders had been observed as early as the Royal Commission of $1873 / 74$. The commission noted that apart from urgent and accident cases admission to Sydney Infirmary was either by subscriber's recommendation or Colonial Secretary's order. ${ }^{59}$ In each case the prospective patient was subject to a medical examination prior to admission, which had the effect of certifying medical need. The subscriber or the government was the guarantor of the financial need. But private subscribers were thought not to make the necessary checks and the hospital was in no position to refuse their recommendations on other than clearly established medical grounds. The issuing of the Colonial Secretary's order was a formal process whereby either a respectable citizen recommended the patient (making government admission only one step removed from the

${ }^{58}$ C.S.I.L., op. cit., note 6 above, 85/4279, with C.S.S.B., op. cit., note 2 above, 4/896.1.

s3 Ibid., 85/5554.

s4 Ibid., 86/649, 86/3083.

ss Ibid., 86/4156.

se Ibid., 86/4898.

${ }^{87}$ Ibid., 86/4696 with $86 / 7561$.

${ }^{88}$ Ibid., 86/7561.

so Royal Commission on Public Charities, 1st Report, 1873/74, V. \& P.L.A., vol. 6, pp. 97 ff. 


\section{Michael Horsburgh}

subscriber's recommendation) or, more usually, the patient was referred to the government by the infirmary itself, after the medical need had been assessed. The acceptance of this arrangement virtually guaranteed payment for any person who presented himself to the hospital. Under it the government paid for about two-thirds of the inmates of the infirmary. ${ }^{80}$

The solution to this problem was found in the abolition of the direct system of orders and the opening, in 1884, of the Hospitals Admission Office, where cases were assessed by the inspector of public charities and a government medical officer. As an alternative to admitting patients to the metropolitan hospitals, the office could send them to an appropriate government institution, including the newly opened Coast Hospital. ${ }^{61}$ Even so, the hospitals required some authority to admit urgent cases without first sending them to the admission office. In August 1885, Robison drew attention to the excessive number of patients admitted in this way. These patients were able to escape "the ordeal of the Inspector's inquiry", and he suggested that the numbers could be controlled if those patients were not eligible for per capita payment, but chargeable to the hospitals' general revenue. ${ }^{62}$

In November 1886 the operation of the admission office was entirely assumed by the medical adviser to the government. ${ }^{63}$ The rates of payment for patients admitted continued to be negotiated as before until 1905 when the system was altered to a general subsidy of $£ 35$ per annum per approved hospital bed. ${ }^{64}$ This move, while not avoiding the necessity for periodic re-evaluation of the rate, or ruling out disputes about the manner of its computation, did make it to the advantage of the hospital to reduce the numbers of non-paying patients and receive both bed-subsidy and patients' fees. In so doing it placed yet another difficulty in the way of the poor who might need hospital care.

\section{THE CENTRAL HOSPITAL BOARD}

An alternative proposal for the control of the metropolitan hospitals was a central board of management. It emanated from Colonial Secretary Alexander Stuart in August $1883 .{ }^{65}$ In response to a request from Sydney Hospital for a $£ 50,000$ capital grant, Stuart expressed reservations about the Macquarie Street site as the location of a general hospital. He favoured Prince Alfred Hospital, but in any case the entire hospital situation required rationalization to prevent competition between institutions, to ensure accommodation for the various classes of patients and to make the most economical use of available resources. An integral part of an effective system would be a central board.

Stuart circulated his proposal to a number of eminent medical persons in the city and received favourable support. Dr. MacLaurin thought the board should have a

$\infty$ Ibid., p.44.

11 Journal of the Legislative Council of New South Wales (J.L.C.), 1883/84, vol. 3, p. 1162.

62 C.S.I.L., op. cit., note 6 above, 85/9682, with C.S.S.B., op. cit., note 2 above, 4/896.1. In the period he was reviewing, 431 patients had been so admitted, 235 to Prince Alfred Hospital and 196 to Sydney Hospital.

as C.S.I.L., op. cit., note 6 above, 86/11372.

at Ibid., 07/13495, with C.S.S.B., op. cit., note 2 above, 5260 .

6 Correspondence re hospital accommodation for the City of Sydney, J.L.C., op. cit., note 61 above, p. 1177. 


\section{Issues in the government subsidy of hospitals in New South Wales}

full-time chairman. ${ }^{68}$ Mackellar, medical adviser to the government, also agreed. ${ }^{67}$ Sir Alfred Roberts suggested that each hospital should have its own house committee with both elected and appointed members and that the chairman, treasurer, honorary secretary and one government member of each house committee should make up the central board. ${ }^{68}$ The inspector of public charities was also in favour. ${ }^{69}$ It was not clear, however, either in the original minute, or in any comments upon it, what precise division of responsibility should devolve on the board and the respective hospital authorities. Since both Sydney and Prince Alfred Hospitals were incorporated by statute, any move would have required either their full co-operation or to have been made the subject of overruling legislation. On the basis of the support he received, Stuart declined to provide funds for the rebuilding of Sydney Hospital. ${ }^{70}$ He expanded further on his plan in September, 1885 in a minute which proposed a comprehensive reorganization of the city hospitals along the same lines. ${ }^{71}$ On that occasion, MacLaurin was not in support. ${ }^{72}$ The plan failed to come to fruition when Stuart suffered a heart attack and could not continue in office. ${ }^{73}$

\section{CAPITAL GRANTS FOR METROPOLITAN HOSPITALS}

The erection, with government support, of large hospitals presupposes a policy by which both the location and development of the institutions is to be guided. The history of subsidy to the metropolitan hospitals is in a real sense the entire public history of the development of a policy of public provision of health care. It is not the intention here to enter upon such a broad range of issues. Instead the implications of the payments will be pursued in a limited manner. The payment of large amounts of subsidy to the two hospitals made them appear to be state institutions, in contrast with their formal voluntary status.

Such an attitude towards an ostensibly private organization arose in the dispute over the appointment of the Royal Commission to inquire into the death of David Gibson in Sydney Infirmary in 1866. 74 Attorney-General Manning asserted the public interest in the infirmary at that time. In 1868 , when the infirmary requested a deed of grant of its Macquarie Street property, the Martin government refused. Its chief argument was that the infirmary was, by reason of public support, a public institution and that the government ought to retain control of the land. ${ }^{75}$ The Infirmary authorities were naturally aggrieved, since previous governments had promised to issue appropriate grants, and government behaviour had consistently implied that the land was the infirmary's. ${ }^{76}$ Inconsistency of treatment was also

os Ibid., p. 1179.

${ }^{\circ}$ Ibid., p. 1180.

ss Ibid., p. 1185.

os Inspector of Public Charities, 8th Report, V.\& P.L.A., op. cit., note 5 above, 1883/84, vol. 6, p. 694. 9th Report, ibid., 1885/86, vol. 2, p. 594.

${ }^{70}$ Correspondence re hospital accommodation, J.L.C., op. cit., note 61 above, p. 1185.

${ }^{71}$ Dated 2 September 1885, with C.S.S.B., op. cit., note 2 above, 4/896.1.

72 Ibid., C.S.I.L., op. cit., note 6 above, 85/12418.

73 Dickey, op. cit., note 33 above, p. 231.

"2 Correspondence re David Gibson, V. \& P.L.A., op. cit., note 5 above, 1866, vol. 4, pp. $23 \mathrm{ff}$. Appointment of a commission to inquire into Sydney Infirmary, ibid., pp. $31 \mathrm{ff}$.

${ }_{75} V . \&$ P.L.A., op. cit., note 5 above, $1868 / 69$, vol. 3, p. 467.

70 Ibid., p. 468. 


\section{Michael Horsburgh}

alleged, since the Benevolent Society and the Randwick Asylum had received grants. ${ }^{77}$ In any case payment on behalf of patients, which was a large proportion of the so-called public support was "business" and not "subsidy". ${ }^{78}$

The government asserted that as a voluntary society the infirmary could not guarantee service to patients, neither had it any enforceable obligation to provide it. The effect of subsidy, however it was provided, was to allow more persons to receive aid than private charity could provide. In de facto, if not de jure terms, Martin said the Sydney Infirmary “... . although in its inception and its management a private, is in substance a public institution." 79 The Martin government took an unusual step in not granting the land to the infirmary, and although the proposal was the subject of a favourable recommendation by a Select Committee in $1870^{80}$ the deeds did not finally issue until $1878 .{ }^{81}$

In his minute of 1885 already referred to, Colonial Secretary Stuart stated:

The time has arrived when I hope the Trustee or Managers of these two Institutions will recognise that they have been by the Government and the public placed in the position of Trustees principally, and in greatest degree, to direct in the most efficient manner the great object of relief to the sick poor and the disabled of this vast city and its surroundings, and only in secondary degree and to the extent of its usefulness of the particular land or buildings placed under their care. ${ }^{82}$

Hospitals existed to fulfil an approved public function and their managers were in no way to be regarded as proprietors. Presumably, if their functions were inefficiently or improperly undertaken, they would be removed by public action.

Consequent upon the passing of the Public Works Act of 1888 capital developments at the metropolitan hospitals were subject to the scrutiny of the Parliamentary Public Works Committee in the same manner as government projects. ${ }^{83}$

The effect of capital grants on the position of hospitals was increased in 1902 by the use of a new method for their erection. Prior to that time, the government had subsidized charitable organizations in respect of buildings which were erected for those organizations by private contractors. For the building of the Queen Victoria Memorial Pavilions at the Prince Alfred Hospital the day labour system, first adopted by the government in 1894, was used. The building was erected under the direct control of the Public Works Department. Government thus entered directly into the capital project, which was itself the subject of some controversy, since it by-passed the regular master builders of the city. ${ }^{84}$ It also confirmed the perception of the major hospitals as part of the government arrangements. Given therefore the nature of medical care, the amount of government subsidy and the inability of voluntary arrangements at any time to provide the service required, the time was ripe for the

77 Ibid., p. 474.

78 Ibid., p. 470.

70 Ibid., p. 472.

20 Ibid., 1870, vol. 2, p. 537.

11 Ibid., 1878/79, vol. 2, p. 938, evidence of F. McKern before the Select Committee on the Sydney Infirmary Bill. See also documents in C.S.S.B., op. cit., note 2 above, 4/818.4.

s2 2 September 1885 , with ibid., 4/896.1.

6s Reports: Sydney Hospital, J.L.C., op. cit., note 61 above, 1891/92, vol. 4, p. 1087; Prince Alfred Hospital, ibid., 1901, vol. 3, p. 1407.

" Report of the Public Service Board on excessive costs, etc., ibid., 1904, vol. 1, p. 999. 
proposition that the government should assume complete control of the hospital system. In view of the close relationship between the services offered and the buildings involved, such control would necessitate the resumption by the government of the properties and the assets of the organization involved, and the transfer of the staff. But it was not until 1911 that acting Colonial Secretary Flowers produced such a plan. ${ }^{85}$ His aim was to remove hospitals from the realm of charities and to assert that it was "absolutely the concern of the State to preserve the life of its citizens."

Service was to be available to all. "This is the inherent defect of the system. The very poor get the same treatment, as a charity, by the same surgeons and physicians, as the very rich get for high fees; but the great middle class have no provision made for them." 87 But Flowers was not successful, ${ }^{88}$ and the question has not yet been resolved.

\section{SUMMARY}

The public hospitals of New South Wales began as charitable institutions for the sick poor and were only with difficulty distinguishable from benevolent asylums. They were the most widespread of all the nineteenth-century charitable endeavours and in rural areas fulfilled a function much broader than the care of acute illness. In theory they were voluntary charities, but in practice were heavily subsidized by government. The forms of subsidy were inflexible, and did not assist the hospitals to develop in response to observed needs. They did, however, imply a substantial public role for the institutions.

Improvements in standards of medical and hospital practice made hospitals more attractive to the non-poor. This changing perception of the role of hospitals, together with increasing public expenditure on them, encouraged the view that government should remove hospitals from the realm of charity to the status of public utility.

\footnotetext{
${ }^{85}$ See documents in C.S.S.B., op. cit., note 2 above, 5244.

80 Flowers quoted in the Daily Telegraph, 16 September 1911.

${ }^{27}$ F. Flowers, A pamphlet on the hospital system in New South Wales, Sydney, W. A. Gullick (Government Printer), 1912, p. 13.

sickey, op. cit., note 33 above, pp. $437 \mathrm{ff}$.
} 